\title{
Land economic rent computation for urban planning and fiscal purposes
}

\author{
Emília Malcata Rebelo* \\ Research Centre for Territory, Transports and Environment, Faculty of Engineering of Oporto University (Portugal), Department of Civil Engineering, \\ Territorial, Urban and Environment Planning Division, Rua Dr. Roberto Frias, s/n, 4200-465 Porto, Portugal
}

\section{A R T I C L E I N F O}

Article history:

Received 1 August 2007

Received in revised form 21 July 2008

Accepted 24 July 2008

\section{Keywords:}

Urbanistic management

Economic land urban rent

Property valuation methods

Surplus values

Offices markets

Hedonic regression models

\begin{abstract}
A B S T R A C T
This article proposes an innovative methodology to compute economic rents of land designed to current or potential offices uses. It consists in the establishment of a cause-and-effect relation between offices' price levels and correspondent levels of land rent, considering the main factors that influence property prices, the ones that guide public and private activities' location decisions and the inter-dependencies between land and real estate property markets. The rationale subjacent to this research is that land economic rent is determined by the difference between offices market price and a set of costs correspondent to land acquisition, planning and building processes, and a profit margin. An assessment of surplus values is provided in order to compute it as the difference between total land market value (land economic rent plus economic return on land use) and correspondent tributary patrimonial-value according to legal valuation proceedings (settled on property law). In order to reach these goals, variables that exert influence on urban planning and municipal management were identified, an urban management information system was designed and implemented, and an integrated and interactive model to support decisions in urban planning - concerning real estate offices and land prices and characteristics - was developed. These tools were applied as a case study to Oporto city (Portugal). They embody updating functionalities, setting up as an on-going support to policies of municipal land use management (particularly applied to offices uses). A proposal is made to integrate similar models in territorial plans as valuation tools to support better approaches to assess the impact of planning decisions on real estate and land values, thus informing a more equitable, efficient and local-based tax basis. Implications of this analysis for urban planning and fiscal settings are proposed.
\end{abstract}

(C) 2008 Elsevier Ltd. All rights reserved.

\section{Introduction}

Territorial planning impacts on land and real estate prices

Territory is a first-order good, where individuals' social and economic life express through a complex network of relations (Pardal, 2006a). Considering urbanism is a public service in the scope of the State, one of the most important attributions of urban planning consists in making land available for the different kinds of uses, according to planned land classifications and assignments, and based on rated prices (Anderson, 2005; Pardal, 2003). Planning shall arrange public and private sectors' tasks and scopes, what implies a territorial strategic perspective where justice, trust and technical and scientific accuracy interact (Pardal, 2006a,b). Urban planning increasingly conditions land uses and values. However, it must not be guided by a strict market rationale, and cannot disproportionately pursue demand needs. Portuguese territorial plans systematically

\footnotetext{
* Tel.: +351 225081482; fax: +351 225081486.

E-mail address: emalcata@fe.up.pt.
}

have lacked to access spatial economic-financial impacts of their performance: (1) they do not appraise the consequences of their contents on the settlement of land and real estate market prices; (2) do not appropriately define how private property shall accomplish its social function; and (3) do not even analyse market segmentation (Pardal, 2006a,b). As (1) new forms of territorial appropriation emerge; (2) clear rules referring to surplus values settlement and distribution do not exist; and (3) the planning system does not delimit central and local administration's scopes; processes of use assignment, values-building and land appropriation become doubtful, and many different agents act outside the law, what creates market uncertainty and suspicion (Pardal, 2004, 2006a). Landowners try to reach the maximum possible profit margin when they sell land to developers, but this increases risk the latters face. Promoters, public administration (through taxes), and credit institutions (through credit offer to development and construction), by their turn, all fight to keep surplus values as high as they can (Pardal et al., 1996). Besides, as local territorialities have assumed increased relevance, land users are more and more dependent on state and municipal institutions, as well as on granted firms that explore infrastructures' and services' networks, that manipulate territory 
and, together with plans, threaten property rights, and - as a matter of fact - collect monopoly prices and rents (Pardal, 2003, 2004).

\section{Theoretical background}

Public central and local administration's strategies look forward to balance and coordinate population's and institutions' free initiatives, on the one hand, with a more regulating and normative planning performance, on the other, in order to avoid strong intra and inter-urban and regional imbalances, thus assuring better urban living conditions. Mechanisms of tertiary sector's prices formation - particularly concerning offices prices - and their relations to current land rents, seems to reflect deep dynamics whose causes and effects should be analyzed, as well as the influences they exert on urban development.

Both real estate and land price levels are influenced (1) by supply and demand amounts and elasticities (Harter-Dreiman, 2004; Lipsey and Chrystal, 1983; Rebelo, 2003); (2) by the structures of real estate and land markets; (3) by how much firms are willing to pay for their sites; and (4) by how much promoters/builders are willing to pay for land. As a consequence, land prices condition real estate prices, and at the same time, are conditioned by them (Clark, 1995; Granelle, 1970; LeFeber, 1958; Thoman et al., 1968).

According to neo-classical urban economists, whenever competition exists for land uses, real estate assets' prices exert influence on land plots (George, 1879; Ricardo, 1817; Smith, 1843). This assumption is, furthermore, the foundation of the "backwards method" to compute land values that assume promoters play a core role in real estate markets (Aydalot, 1985; Topalov, 1973). Nevertheless, other authors defend that land actively intervene in real estate price settlement as a consequence of planning orders and of firms' location choices due to land heterogeneous characteristics and competition for specific plots' use (Dunn, 1954; Dunse and Jones, 2002; LaFountain, 2005; Needham, 1981). Under the Marxist perspective, as landowners block up supply, urban centres' land values strongly condition built spaces' prices through high absolute and monopoly rents that enter real estate production costs (Harvey, 1985).

When price of land used as a productive factor surpasses its transference cost (that corresponds to capitalised revenue of its productive use), then it receives an economic rent that equals this surplus (Chacholíades, 1986). It means that, whereas transference cost is a component of real estate cost (and thus, enters in real estate price settlement); economic rent is determined by real estate product's price. But as economic land rent includes a land surplus value and an additional profit margin, and it is very difficult to distinguish between rent and profit, urban planning shall regulate profits, considering land social function, on the one side, and the need to stimulate real estate promoters' initiatives and investments, on the other.

\section{Goals and strategies of a land use policy}

The goals that shall guide a sustained land use policy are (Correia, 1993): to support urban planning and its implementation; (2) to search for a better equity balance in urban development; and (3) to exert influence on land and real estate's prices and profit levels. The latter can be reached, namely, through prosecution of the following underlying goals (Correia, 1993): (1) to keep land prices at acceptable levels; (2) to define and quantify surplus values to be collected by public administration; (3) to prevent land speculation and, if it persists, to make clear the part of its value to be recovered by society in general; and (4) to avoid speculation on land favourably acquired from state. Implementation of these goals may be reached through the application of different land policy tools, based on straightforward or indirect interventions of urban planning and/or through fiscal tools (Correia, 1993; Lichfield and Darin-Drabkin, 1980; Smolka and Amborski, 2003). Thus, according to political implications, urban planning can (1) exert control on specific urban development of sites and uses (not involving or temporarily involving land property by public administration, or through direct participation of public administration in public-private partnerships); (2) exert control on general or particular urban development through fiscal tools; or (3) exert general influence on land markets through dissemination of information and guidelines on public participation (Correia, 1993).

Values of land plots depend on land use policy that settle juridical, economic, administrative and functional land appropriation rules (Pardal, 2006a). They have, then, a territorial-based component - that depends on location, dimension, juridical status and allowed use and respective intensity, which are factors controlled by plans and society - and other component that results from landowners initiatives and investments, that consequently should be taxed at a different rate (Arnott and Petrova, 2006; Correia, 1993; Lee, 2003; Pardal, 2004, 2006a). Therefore, land territorial-based value represents the price - settled by land policy - that should be reasonably supported by socio-economic activities that use it (Lee, 2003; Pardal, 2006a).

Surplus values translate price increases that result from its change of use or from use intensification, or - indirectly - from public investments. They are engendered by administrative decisions concerning urbanisation choices, and correspond to qualifications of the territorial system; thus they are independent from landowner investments. The lack of clearness, monitoring and control over surplus values generation and distribution sustain speculative price-levels, and punishes the sector of civil construction, on the one side, and final buyers of real estate units, on the other (Pardal et al., 1996).

A convenient assessment of property and surplus values taxes requires a conceptual framework that relates territory to society, which is featured by deep changes in real estate property law in what concerns development rights and restrictions settled by plans (Pardal, 2004, 2006a). In many European countries city councils detain a set of land plots that they make available in the market whenever alternative private plots reach excessive high prices. This way, municipalities are able to deal with land speculation. United States, Canada and Latin America public administration use different surplus values appropriation tools that include conventional taxes and urbanisation rates - the former and the latter with different percentages and tributation basis, according to countries as well as urban policy's ruling tools - with different attributes (Smolka and Amborski, 2003).

Autarchies' best way to exert control over all surplus values is to keep them before land enters competitive market. This happens when they are able to take land as public property, selling it in public auction after urban development is performed (Gwin et al., 2005; Hong, 1998; Peto, 1997; R.I.C.S., 1996). This procedure disciplines urban development, balances land market, and does not engender conflict situations. In Portuguese current planning system, however, the majority of urbanisation works is performed by private agents, thus surplus values mingle with infrastructure costs and with profits, therefore public administration looses the prerogative to retain resulting surplus values (Correia and Silva, 1987; Pardal, 2006a). They can, however be reassessed through taxes on property (Smolka and Amborski, 2003). Real estate taxes are based on the principle of the benefit attached to each kind of property. As its taxation over other forms of property will likely engender social inequalities, it must be justified by (1) the warrant of property rights and status given 
to landowners by public administration; (2) services rendered to landowners by maintenance of infrastructures' networks; (3) and support to land structure that underlies land economic values (Pardal, 2006a). Therefore property tax exclusively falls upon territorial-based value, independent of landowner's investments and improvements, thus it warrants neutrality of landowners' interests in face of uses and intensities of use proposed by plans (Arnott and Petrova, 2006).

In Portuguese law surplus value tax falls upon real estate value's rise between acquisition and selling price. However, part of this increase in value may correspond to profits and plots' increased worth due to landowners initiatives in face of market dynamics. That is why surplus values are usually indefinite and hard to compute. Additionally, general law and plans lack mechanisms to assess surplus values impacts on real estate markets. Within the framework of a just and equitable land policy, a procedure must be settled in order to compute, monitor and control surplus values formation and allotment, thus avoiding and fighting speculative behaviours (Pardal et al., 1996). Parameters should be clearly stated in order to compute how much is added or withdrew from a certain land plot's value as a result of changes in use or use intensities, in public investments, or in building coefficients or other ruling factors that emerge from plans or planning decisions, that exert impact on property rights (Pardal, 2004, 2006b).

Urban planning should also exert control on real estate prices properly so-called, thus methodologies to settle parameters or to compute surplus values should also avoid opportunistic appropriation of speculative profits by promoters (Correia, 1993; Pardal, $2006 \mathrm{~b})$. In the absence of these proceedings, political, technical and administrative parts that intervene in regulation and licensing of land use and buildings will enter for the power to change land uses or intensities of use (Pardal, 2006a).

These reflections justify the development of a set of tools in order to monitor, supervise and control real estate and land prices formation and evolution, aimed at supporting municipal power decisions concerning land uses, changes of use and respective intensities, asserting co-ordination of economic development policies. These studies should be founded on a deep understanding of land and real estate markets' structures, performance and local characteristics, and applied to specific functional areas.

\section{Materials and methods}

\section{Goals and structural outline}

Considering that (1) urban planning should guarantee availability of land and real estate products needed to the different functional uses, at acceptable prices; (2) it should also avoid generation of excessive profits upstream and downstream development's supply and demand chain; (3) neutrality of landowner's interests in face of dynamic changes in land use and intensity of use anticipated by planning can only be reached through parameter setting and control over surplus values distribution; and that (4) in order to control speculative behaviours urban planning must carry out property legislation, on the one side, and dispose of land and real estate evaluation tools that fit each site, use and specific intensity of use, on the other, the goals pursued in the research reported in this article consist of:

- Identification and quantification of the variables that best describe mutual influences between urban planning and urbanistic management, and exert influence on the price of offices and land aimed at offices buildings.

- Design and implementation of an urbanistic management information system to monitor the behaviour and evolution (1) of those variables, as well as (2) of different kinds of land, planning and building costs, and (3) of offices price levels, land economic rents, and surplus values generated on land targeted to offices uses.

- Enhancement of urban planning and municipal power intervention in order to regulate, guide, coordinate and control land uses, respective values, and property markets' performance, through development of an integrated and interactive model - aimed at analyzing, supporting and guiding municipal decisions in what concerns offices undertakings and respective land plots.

- Development of an on-going methodology for the appraisal of land economic rents and surplus values - that accrue from urban planning decisions and from public investments performed based on the application of property legislation and strictly related to local-based sites' urbanistic and socio-economic characteristics. Proposal to introduce this kind of surplus values evaluation models on territorial plans, as forms to monitor and control surplus values generation and distribution.

The methodology pursued in order to achieve these goals consist (1) in the organization, design and implementation of a set of databases and of an urban management information system for Porto city (SIGUP); (2) adjustment of a hedonic function for office market price valuation, and quantification of the main explanatory variables; (3) computation of average urbanisation and technical building costs; management, commercialization, administrative, marketing and financial costs, taxes, and normal profit margin; (4) reckoning of land economic rent and of surplus values of urban land aimed at offices uses; (5) definition of an integrated mathematical simulation model, with an interactive cartographic display interface in order to (a) simulate municipal power agents' and/or private agents' performance on offices market prices and characteristics, and on rents of land aimed at offices' uses; (b) centralise the display of alternative urban policies' expected results; and (c) monitor and control offices' prices and land for offices' economic rents and surplus values, according to different alternative scenarios of urbanistic performance; and (6) extraction of implications for urban planning and taxation purposes.

This model is settled by a set of inter-related modules - that consist in the design and implementation of an hedonic econometric surface for offices prices $/ \mathrm{m}^{2}$, as well as in the computation of different kinds of costs, rents and surplus values of land pointed at offices uses -, and respective cartographic display through an interface developed in geographic information systems (Fig. 1).

\section{Urban management information system for Oporto city}

Oporto city is the centre of Oporto Metropolitan Area (Portugal). It has three main offices areas: (1) Marquês de Pombal Square/Constituição area; (2) Gonçalo Cristóvão area (traditional offices area and Oporto downtown); and (3) Boavista Avenue and Rotunda area (Fig. 2).

A set of databases was developed concerning (1) land plots' location and characteristics; (2) different kinds of costs involved in offices urbanisation, construction, and trade; (3) offices locations and features; and (4) the Urban Management Information System for Oporto City (SIGUP). The later was implemented through data gathering and treatment concerning a set of urbanistic indicators of office mainly-searching activities: law, economy, engineering and architecture, banks and insurance companies, real estate activities, informatics activities, and other services lent to firms. It was especially designed for the purposes of this research as (1) a "tableau de bord" for monitoring the evolution of these variables, on the one side, and as (2) a set of potential explanatory variables of offices market prices. The information was collected, systematised, and 


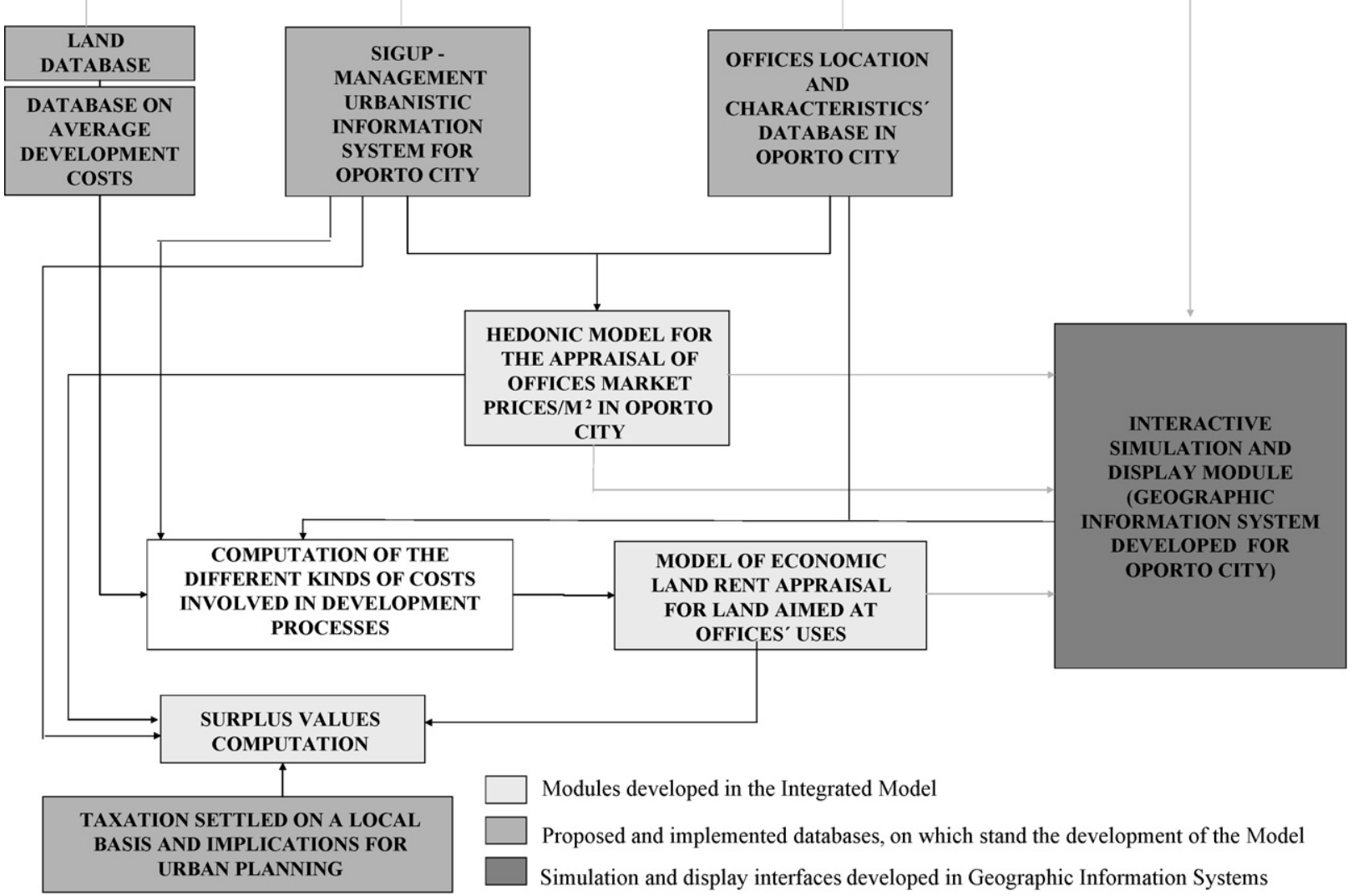

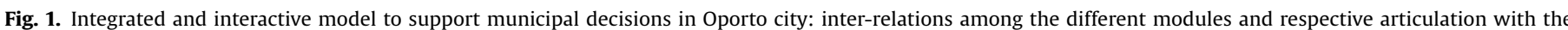
display and simulation cartographic interface.

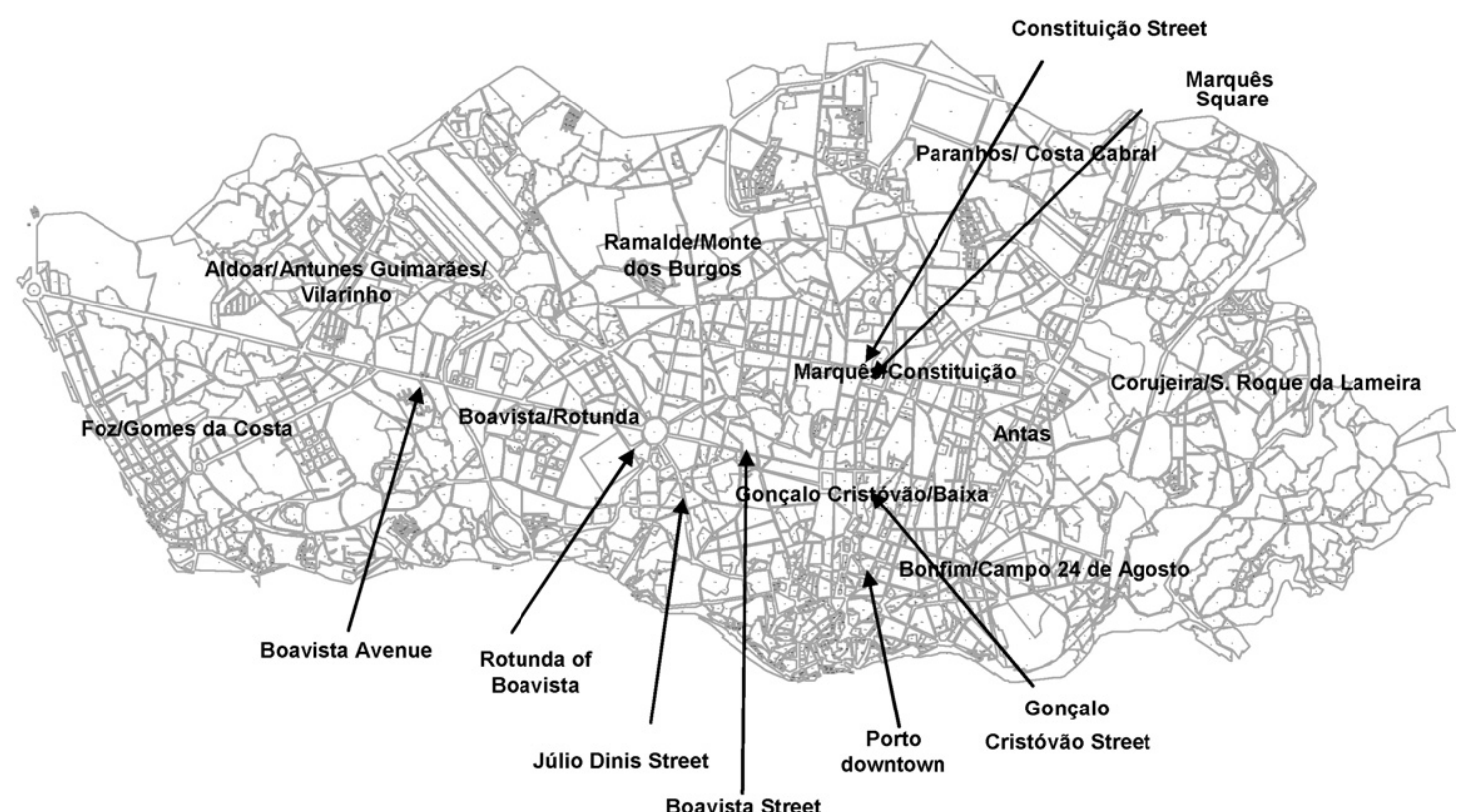

Boavista Street

Oporto city (blocks)

Fig. 2. Blocks and main offices' areas in Oporto city.

Please cite this article in press as: Rebelo, E.M., Land economic rent computation for urban planning and fiscal purposes. Land Use Policy (2008), doi:10.1016/j.landusepol.2008.07.008 
cartographically displayed through a developed cartographic interface. In SIGUP were systematised the following variables (Rebelo, 2003, 2004):

- Spatial location - The adopted measures for spatial location were each office's cartographic geo-referentiation in a system of orthogonal axis, and the areas of the quarters where each office stands (in $\mathrm{m}^{2}$ ).

- Urban planning ordinances - The selected variables were zoning ordinances and coefficients of land occupation, both established in 1993rd Oporto Municipal Master Plan - that devoted great specialized concern to zoning of functional land uses. In order to incorporate in de analysis the impact central plan-settled area (Boavista area) seems to exert on offices location and features, it was treated as a dummy variable: if a certain office belongs to central area it was attributed the value 1 and 0 otherwise.

- Location indexes of law, economics, engineering and architecture, banks and insurance companies, real estate, informatics, and other services to firms' activities - The location index of a certain activity is computed by the relation between the number of activities of the same kind and the total number of activities of the superior tertiary sector in a certain axis (branch of a road), divided by the relation between the number of activities of the same kind and the total number of the superior tertiary sector's activities in the whole city. These variables identify location differences, according to the specific kind of activity under analysis.

- Weighted distance to Rotunda of Boavista - This measure translates accessibility conditions to Oporto recent and planned central business district (Rotunda of Boavista), and is computed as the effective course time to this place - taking different access alternatives from various origins, in morning rush hour.

- Temporal inertia of office activities (taking as reference the total number of offices of the studied activities existing in Oporto in 1999) - This set of indicators identify the celerity or inertia in office location changes, entrance in or departure from offices market. They are computed, for a certain axis, by the percentage of offices that remained in the same location, changed location, entered, or left the market during the 90th decade.

- Public investments - These variables correspond to the different kinds of investments performed by the Oporto City Council, as are reported in respective plans and budgets: investments $/ \mathrm{m}^{2}$ in (1) communications and transports; (2) culture, sports and leisure time; (3) sewerage and salubrity; (4) environment; (5) education; (6) habitation; (7) economic development and tourism; (8) civil protection; (9) social action; (10) urbanistic qualification; (11) other goals; and (12) total investments. These indicators (expressed in euros per $\mathrm{m}^{2}$ of parish, of quarter or of the whole Oporto city, according to their respective location and scope) allow the analysis of how public investments condition market prices in offices' real estate market, according to their spatial location.

- Number of people working in the superior tertiary sector by quarter - Considering the number of employees in the superior tertiary sector is a good indicator of tertiary activities' level; it allows the analysis of the influence it exerts on offices prices.

- Date.

\section{Results}

\section{Hedonic appraisal model of offices prices $/ m^{2}$}

This section reports the design of the hedonic market appraisal model for the whole offices population effectively existent in Oporto city (be it in the market for sale or not - in the latter circum- stances the model points out respective intrinsic values) (Dunse and Jones, 1998; Nappi-Choulet et al., 2007; Nitsch, 2006). It is assumed offices market prices represent transaction prices and depend, mainly, on urban characteristics, as offices' structural features are near one another (Nitsch, 2006). Although the model was first designed from data concerning the 90th decade, it still remains applicable, using the same methodology with new and/or updated information.

First of all, a sample of offices was extracted from developed databases. Then a Kruskal-Wallis non-parametric statistical test was performed which led to the conclusion that the hypothesis that the sample arises from population could not be rejected - indeed it was representative of Oporto total offices' population, with a 5\% significance level.

As the number of variables considered in the databases was high and many were strongly correlated (Rebelo, 2003), then an analysis in principal factors was pursued (Bourassa et al., 1999) - using the principal components extraction method and the varimax with Keiser normalization rotation method. ${ }^{1}$ It can be noticed that nine principal factors, expressed as linear combinations of original variables and orthogonal among one another, explain about $70.9 \%$ of total data variance (Table 1 points out factors' composition from the original variables, and variance they manage to explain).

Considering offices asking prices per square meter as the dependent variable, and principal factors as independent variables, the hedonic adjustment leads to an explained variance of $67.8 \%$. Respective coefficients figure out market prices at which market (real or potential) implicitly values each individual attribute (Bourassa et al., 1999; Nappi-Choulet et al., 2007; Rosen, 1974), despite mingled within a bundle of attributes traded together in a single unit (Table 1):

Factor 1 that depicts urban planning and public investments succeeds in explaining the highest variance slice (18.3\%) - it subsumes variables under urban planning control. As location indexes translate relative concentration of certain activities, they are strictly linked to land occupation patterns in Oporto city. Engineering and architecture activities generally have small dimension and scatter throughout all city territory, what is particularly relevant in the explanation of Factor 4. Location of law activities, by their turn, strongly concentrates around the municipal court of justice, deep inside the historical area. These activities are older steady ones - as reflected by negative loading of informatics' activities location index in Factor 5 - thus this proximity turns up to be deeply important in their offices location. Despite it have not been explicitly considered, this factor translates distance to Oporto's historic/traditional centre. Factor 6 translates near location of economic activities, territorially concentrated, and developed in offices buildings, where offices take advantage both of internal and external economies.

Factors most valued by the market that, as a result, exert higher upward influences on market prices $/ \mathrm{m}^{2}$ ) represent economies of scale (Factor 6), the tendency Oporto offices exhibit to search for traditionally centred (downtown) city locations (Factor 8), quality of the environment (Factor 9), public security concerns (Factor 3), distance to modern planned CBD (Factor 2), offices scattering throughout city territory (Factor 4), dimension of the superior tertiary sector (Factor 7), urban planning and municipal investments $/ \mathrm{m}^{2}$ in urban qualification and accessibilities (Factor 1 ), and offices location near the historical centre (Factor 5). However initially considered, date is not an explanatory variable, what goes along with recent tendencies of offices market prices stagnation in

\footnotetext{
${ }^{1}$ In the statistical analysis reported in this article was used software SPSS 14.0.
} 
Table 1

Principal factors, original variables most related to them, and parameters of the linear model for the determination of offices prices $/ \mathrm{m}^{2}$ in Oporto city

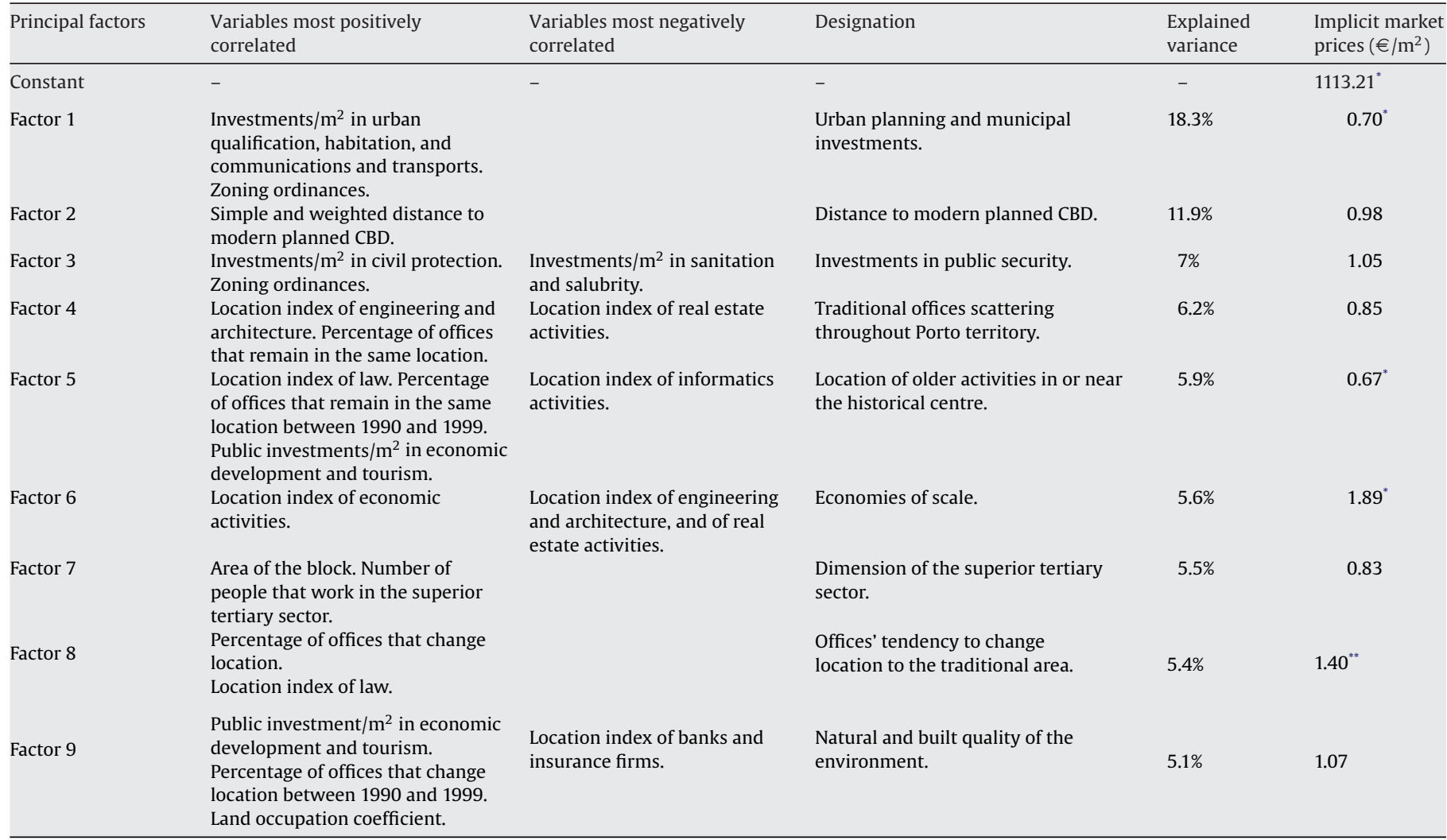

${ }^{*}$ Coefficients significant at $5 \%$ level.
Coefficients significant at $10 \%$ level.

Oporto city. Market prices $/ \mathrm{m}^{2}$ stand on a rather high reference value of about $1113 € / \mathrm{m}^{2}$ - what translates their near structural attributes (Nitsch, 2006) - and urban planning ordinances, distance to central locations, specific characteristics of the environment, activities' relative location and steadiness, among others, add to this officepatterned value.

In order to generalize the model to the whole Oporto offices' population, a cluster analysis was carried through (using data from SIGUP) (Bourassa et al., 1999; Dunse and Jones, 2002; Morphet, 1997). It allowed the identification of two main segments in the offices market. Further, a discriminant analysis was applied in order to allocate all superior tertiary offices in Oporto city to one of both identified clusters. The classification matrix obtained leads to the conclusion that $20.3 \%$ of whole offices population belong to first market segment and $79.7 \%$ belong to the second one.

Market segments show different offices' locations, price levels and characteristics: whereas the first one is set up by offices with low prices, located in buildings with diversified functional occupations and exhibit a scattered pattern in the whole Oporto city, the second segment is mainly made up by firms' offices, located in specific office buildings in consolidated areas of the tertiary economic sector (traditional centre) or around the modern central business district (Rotunda of Boavista), in a layout provided with good accessibilities. The latter - that corresponds to institutional offices segment - exhibits higher prices that result from real estate agents interventions, from marketing policies, and from the promoters bet on a symbolic image of quality. They mainly locate in downtown, traditional and historic Oporto city areas, as well as along Boavista Avenue and Constituição Street (that links western to eastern city zones).
Next step consists in the application of the hedonic regression model in order to estimate offices real or potential selling prices $/ \mathrm{m}^{2}$, according to respective market segments (Fig. 3).

In order to express offices selling prices $/ \mathrm{m}^{2}$ as a function of database's variables, a change of basis was accomplished: thus the implicit value per unit of each original variable (Dubin, 1998) results from the sum of the product between the unitary prices (regression coefficients) of the nine principal factors and the line values corresponding to this variables in the matrix that transforms the original variables in the principal factors (matrix of factor scores) (Rebelo, 2003).

\section{Computation of different kinds of costs}

According to the hypothesis established in the research project reported here, land economic rent is given by the difference between the total expected income and a set of anticipated land, urbanisation, technical building, and attached costs (administration, management, commercialization and financial costs), taxes, and a normal profit (expressed as a multiple of all those costs) (Aydalot, 1985; Topalov, 1973).

Legal guidelines and planning restrictions allow the construction of a certain area or volume in each building site. Total expected income in real estate offices is, then, given by the product of land occupation index, total construction surface, and selling price $/ \mathrm{m}^{2}$ - anticipated by the hedonic model weighted by the percentage of offices in tertiary sector's undertakings.

An estimate of average values of all kinds of costs for all offices geo-referenced locations currently existent in Oporto city was 
Table 2

Prices $/ \mathrm{m}^{2}$ and different kinds of costs $/ \mathrm{m}^{2}$ involved in land acquisition and offices building, according to their location in Oporto city (excerpts of the database)

\begin{tabular}{|c|c|c|c|c|c|c|c|c|c|c|c|c|c|c|c|c|c|c|c|c|}
\hline \multirow[t]{2}{*}{ Address } & \multirow[t]{2}{*}{ Area of Oporto city } & \multicolumn{10}{|c|}{ Land acquisition costs $/ \mathrm{m}^{2}$} & \multicolumn{3}{|c|}{ Building costs $/ \mathrm{m}^{2}$} & \multicolumn{6}{|c|}{ Financing costs $/ \mathrm{m}^{2}$} \\
\hline & & $\begin{array}{l}\text { Anticipated } \\
\text { selling } \\
\text { pricess } / \mathrm{m}^{2} \\
\left(€ / \mathrm{m}^{2}\right)\end{array}$ & $\begin{array}{l}\text { Land } \\
\text { cost } / \mathrm{m}^{2} \text { of } \\
\text { offices } \\
\text { buildings }\end{array}$ & $\begin{array}{l}\text { Transfer } \\
\text { tax }\end{array}$ & $\begin{array}{l}\text { r Stamp } \\
\text { duty }\end{array}$ & $\begin{array}{l}\text { Property } \\
\text { registration } \\
\text { costs }\end{array}$ & $\begin{array}{l}\text { Notarised } \\
\text { costs }\end{array}$ & $\begin{array}{l}\text { Lawyers } \\
\text { hono- } \\
\text { raries }(0, \\
5 \%)\end{array}$ & $\begin{array}{l}\text { Accrued } \\
\text { value on } \\
\text { lawyers } \\
\text { honoraries }\end{array}$ & $\begin{array}{l}\text { Urbanisation } \\
\text { costs }\end{array}$ & $\begin{array}{l}\text { Total land } \\
\operatorname{cost} / \mathrm{m}^{2}\end{array}$ & $\begin{array}{l}\text { Average } \\
\text { offices } \\
\text { building } \\
\text { costs (and } \\
\text { specialised } \\
\text { works) }\end{array}$ & $\begin{array}{l}\text { Average } \\
\text { garage } \\
\text { building } \\
\text { costs } / \mathrm{m}^{2} \\
\text { of offices } \\
\text { buildings }\end{array}$ & $\begin{array}{l}\text { Total } \\
\text { offices } \\
\text { building } \\
\text { costs } / \mathrm{m}^{2}\end{array}$ & $\begin{array}{l}\text { Management, } \\
\text { administra- } \\
\text { tive and } \\
\text { marketing } \\
\text { costs } / \mathrm{m}^{2}\end{array}$ & $\begin{array}{l}\text { Financing to } \\
\text { acquisition } \\
\text { costs } / \mathrm{m}^{2}\end{array}$ & $\begin{array}{l}\text { Financing to } \\
\text { commerciali- } \\
\text { sation } \\
\text { costs } / \mathrm{m}^{2}\end{array}$ & $\begin{array}{l}\text { Total } \\
\text { financing } \\
\text { costs } / \mathrm{m}^{2}\end{array}$ & $\begin{array}{l}\text { Tax on } \\
\text { property/ } \\
\mathrm{m}^{2}\end{array}$ & $\begin{array}{l}\text { Total } \\
\text { | costs/ } \\
\mathrm{m}^{2}\end{array}$ \\
\hline $\begin{array}{l}280 \text { RUA EUGENIO } \\
\text { CASTRO R }\end{array}$ & Boavista/Rotunda & 44.4 & 290.0 & 29.0 & 1.2 & 1.5 & 1.5 & 1.5 & 0.2 & 31.5 & 356.3 & 415.0 & 43.8 & 458.8 & 3.7 & 11.0 & 0.1 & 11.1 & 0.770 & 830.6 \\
\hline $\begin{array}{l}300 \text { RUA EUGENIO } \\
\text { CASTRO R }\end{array}$ & Boavista/Rotunda & 109.0 & 290.0 & 29.0 & 1.2 & 1.5 & 1.5 & 1.5 & 0.2 & 31.5 & 356.3 & 415.0 & 43.8 & 458.8 & 3.7 & 11.0 & 0.1 & 11.1 & 0.770 & 830.6 \\
\hline $\begin{array}{l}352 \text { RUA EUGENIO } \\
\text { CASTRO R }\end{array}$ & Boavista/Rotunda & 109.0 & 290.0 & 29.0 & 1.2 & 1.5 & 1.5 & 1.5 & 0.2 & 31.5 & 356.3 & 415.0 & 43.8 & 458.8 & 3.7 & 11.0 & 0.1 & 11.1 & 0.770 & 830.6 \\
\hline $\begin{array}{l}\text { 370 RUA EUGENIO } \\
\text { CASTRO R }\end{array}$ & Boavista/Rotunda & 44.4 & 290.0 & 29.0 & 1.2 & 1.5 & 1.5 & 1.5 & 0.2 & 31.5 & 356.3 & 415.0 & 43.8 & 458.8 & 3.7 & 11.0 & 0.1 & 11.1 & 0.770 & 830.6 \\
\hline $\begin{array}{l}\text { 686 RUA TENENTE } \\
\text { VALADIM R }\end{array}$ & Boavista/Rotunda & 109.0 & 290.0 & 29.0 & 1.2 & 1.5 & 1.5 & 1.5 & 0.2 & 31.5 & 356.3 & 415.0 & 43.8 & 458.8 & 3.7 & 11.0 & 0.1 & 11.1 & 0.770 & 830.6 \\
\hline $\begin{array}{l}174 \text { CAMPO MARTIRES } \\
\text { PATRIA CPO }\end{array}$ & $\begin{array}{l}\text { Gonçalo Cristóvão/ } \\
\text { Baixa }\end{array}$ & 109.0 & 281.5 & 28.2 & 1.1 & 1.4 & 1.4 & 1.4 & 0.2 & 31.5 & 346.8 & 415.0 & 43.8 & 458.8 & 3.7 & 10.7 & 0.1 & 10.8 & 0.770 & 820.8 \\
\hline $\begin{array}{l}46 \text { CAMPO MARTIRES } \\
\text { PATRIA CPO }\end{array}$ & Gonçalo Cristóvão/Baixa & 44.4 & 281.5 & 28.2 & 1.1 & 1.4 & 1.4 & 1.4 & 0.2 & 31.5 & 346.8 & 415.0 & 43.8 & 458.8 & 3.7 & 10.7 & 0.1 & 10.8 & 0.770 & 820.8 \\
\hline 9 LARGO ADRO LG & $\begin{array}{l}\text { Gonçalo Cristóvão/ } \\
\text { Baixa }\end{array}$ & 44.4 & 281.5 & 28.2 & 1.1 & 1.4 & 1.4 & 1.4 & 0.2 & 31.5 & 346.8 & 415.0 & 43.8 & 458.8 & 3.7 & 10.7 & 0.1 & 10.8 & 0.770 & 820.8 \\
\hline 48 LARGO FONTINHA LG & $\begin{array}{l}\text { Gonçalo Cristóvão/ } \\
\text { Baixa }\end{array}$ & 109.0 & 281.5 & 28.2 & 1.1 & 1.4 & 1.4 & 1.4 & 0.2 & 31.5 & 346.8 & 415.0 & 43.8 & 458.8 & 3.7 & 10.7 & 0.1 & 10.8 & 0.770 & 820.8 \\
\hline $\begin{array}{l}26 \text { LARGO PROF ABEL } \\
\text { SALAZAR LG }\end{array}$ & $\begin{array}{l}\text { Gonçalo Cristóvão/ } \\
\text { Baixa }\end{array}$ & 44.4 & 281.5 & 28.2 & 1.1 & 1.4 & 1.4 & 1.4 & 0.2 & 31.5 & 346.8 & 415.0 & 43.8 & 458.8 & 3.7 & 10.7 & 0.1 & 10.8 & 0.770 & 820.8 \\
\hline 54 PRACA FLORES PC & $\begin{array}{l}\text { Gonçalo Cristóvão/ } \\
\text { Baixa }\end{array}$ & 6.6 & 281.5 & 28.2 & 1.1 & 1.4 & 1.4 & 1.4 & 0.2 & 31.5 & 346.8 & 415.0 & 43.8 & 458.8 & 3.7 & 10.7 & 0.1 & 10.8 & 0.8 & 820.8 \\
\hline $\begin{array}{l}95 \text { RUA JOAO BAPTISTA } \\
\text { LAVANHA R }\end{array}$ & Foz/Gomes da Costa & 109.0 & 241.5 & 24.2 & 1.0 & 1.2 & 1.2 & 1.2 & 0.2 & 31.5 & 302.0 & 415.0 & 43.8 & 458.8 & 3.7 & 9.4 & 0.1 & 9.4 & 0.8 & 774.6 \\
\hline $\begin{array}{l}67 \text { RUA INFANTE SANTO } \\
\mathrm{R}\end{array}$ & Foz/Gomes da Costa & 109.0 & 241.5 & 24.2 & 1.0 & 1.2 & 1.2 & 1.2 & 0.2 & 31.5 & 302.0 & 415.0 & 43.8 & 458.8 & 3.7 & 9.4 & 0.1 & 9.4 & 0.770 & 774.6 \\
\hline 399 RUA ALEGRIA R & Marquês/Constituição & 70.2 & 226.0 & 22.6 & 0.9 & 1.1 & 1.1 & 1.1 & 0.2 & 31.5 & 284.6 & 415.0 & 43.8 & 458.8 & 3.7 & 8.8 & 0.1 & 8.9 & 0.770 & 756.7 \\
\hline 582 RUA ALEGRIA R & Marquês/Constituição & 109.0 & 226.0 & 22.6 & 0.9 & 1.1 & 1.1 & 1.1 & 0.2 & 31.5 & 284.6 & 415.0 & 43.8 & 458.8 & 3.7 & 8.8 & 0.1 & 8.9 & 0.770 & 756.7 \\
\hline $\begin{array}{l}7742 \text { ESTRADA } \\
\text { CIRCUNVALACAO EST }\end{array}$ & Bonfim/Campo 24 Agosto & 61.8 & 226.0 & 22.6 & 0.9 & 1.1 & 1.1 & 1.1 & 0.2 & 31.5 & 284.6 & 415.0 & 43.8 & 458.8 & 3.7 & 8.8 & 0.1 & 8.9 & 0.770 & 756.7 \\
\hline $\begin{array}{l}7762 \text { ESTRADA } \\
\text { CIRCUNVALACAO EST }\end{array}$ & Bonfim/Campo 24 Agosto & 61.8 & 226.0 & 22.6 & 0.9 & 1.1 & 1.1 & 1.1 & 0.2 & 31.5 & 284.6 & 415.0 & 43.8 & 458.8 & 3.7 & 8.8 & 0.1 & 8.9 & 0.770 & 756.7 \\
\hline $\begin{array}{l}11 \text { LARGO JOSE MOREIRA } \\
\text { SIIVA LG }\end{array}$ & Bonfim/Campo 24 Agosto & 109.0 & 226.0 & 22.6 & 0.9 & 1.1 & 1.1 & 1.1 & 0.2 & 31.5 & 284.6 & 415.0 & 43.8 & 458.8 & 3.7 & 8.8 & 0.1 & 8.9 & 0.770 & 756.7 \\
\hline $\begin{array}{l}116 \text { PRACA MARQUES } \\
\text { POMBAL PC }\end{array}$ & Marquês/Constituição & 17.4 & 226.0 & 22.6 & 0.9 & 1.1 & 1.1 & 1.1 & 0.2 & 31.5 & 284.6 & 415.0 & 43.8 & 458.8 & 3.7 & 8.8 & 0.1 & 8.9 & 0.770 & 756.7 \\
\hline $\begin{array}{l}646 \text { RUA PROF CORREIA } \\
\text { ARAUJO R }\end{array}$ & Antas & 109.0 & 211.5 & 21.2 & 0.8 & 1.1 & 1.1 & 1.1 & 0.2 & 31.5 & 268.4 & 415.0 & 43.8 & 458.8 & 3.7 & 8.3 & 0.1 & 8.4 & 0.770 & 740.0 \\
\hline $\begin{array}{l}94 \text { ALAMEDA ECA } \\
\text { QUEIROS AL }\end{array}$ & Antas & 44.4 & 211.5 & 21.2 & 0.8 & 1.1 & 1.1 & 1.1 & 0.2 & 31.5 & 268.4 & 415.0 & 43.8 & 458.8 & 3.7 & 8.3 & 0.1 & 8.4 & 0.770 & 740.0 \\
\hline $\begin{array}{l}\text { 130 ALAMEDA ECA } \\
\text { QUEIROS AL }\end{array}$ & Antas & 44.4 & 211.5 & 21.2 & 0.8 & 1.1 & 1.1 & 1.1 & 0.2 & 31.5 & 268.4 & 415.0 & 43.8 & 458.8 & 3.7 & 8.3 & 0.1 & 8.4 & 0.770 & 740.0 \\
\hline $\begin{array}{l}194 \text { ALAMEDA ECA } \\
\text { QUEIROS AL }\end{array}$ & Antas & 109.0 & 211.5 & 21.2 & 0.8 & 1.1 & 1.1 & 1.1 & 0.2 & 31.5 & 268.4 & 415.0 & 43.8 & 458.8 & 3.7 & 8.3 & 0.1 & 8.4 & 0.770 & 740.0 \\
\hline $\begin{array}{l}256 \text { ALAMEDA ECA } \\
\text { QUEIROS AL }\end{array}$ & Antas & 44.4 & 211.5 & 21.2 & 0.8 & 1.1 & 1.1 & 1.1 & 0.2 & 31.5 & 268.4 & 415.0 & 43.8 & 458.8 & 3.7 & 8.3 & 0.1 & 8.4 & 0.770 & 740.0 \\
\hline $\begin{array}{l}191 \text { PRACA PEDRA } \\
\text { VERDE PC }\end{array}$ & $\begin{array}{l}\text { Aldoar/Antunes } \\
\text { Guimarães/Vilarinho }\end{array}$ & 44.4 & 205.0 & 20.5 & 0.8 & 1.0 & 1.0 & 1.0 & 0.2 & 31.5 & 261.1 & 415.0 & 43.8 & 458.8 & 3.7 & 8.1 & 0.1 & 8.2 & 0.770 & 732.5 \\
\hline $\begin{array}{l}216 \text { PRACA PEDRA } \\
\text { VERDE PC }\end{array}$ & $\begin{array}{l}\text { Aldoar/Antunes } \\
\text { Guimarães/Vilarinho }\end{array}$ & 109.0 & 205.0 & 20.5 & 0.8 & 1.0 & 1.0 & 1.0 & 0.2 & 31.5 & 261.1 & 415.0 & 43.8 & 458.8 & 3.7 & 8.1 & 0.1 & 8.2 & 0.770 & 732.5 \\
\hline $\begin{array}{l}250 \text { RUA SOEIRO } \\
\text { MENDES R }\end{array}$ & $\begin{array}{l}\text { Aldoar/Antunes } \\
\text { Guimarães/Vilarinho }\end{array}$ & 109.0 & 205.0 & 20.5 & 0.8 & 1.0 & 1.0 & 1.0 & 0.2 & 31.5 & 261.1 & 415.0 & 43.8 & 458.8 & 3.7 & 8.1 & 0.1 & 8.2 & 0.770 & 732.5 \\
\hline $\begin{array}{l}305 \text { PRACA PEDRA } \\
\text { VERDE PC }\end{array}$ & $\begin{array}{l}\text { Aldoar/Antunes } \\
\text { Guimarães/Vilarinho }\end{array}$ & 109.0 & 205.0 & 20.5 & 0.8 & 1.0 & 1.0 & 1.0 & 0.2 & 31.5 & 261.1 & 415.0 & 43.8 & 458.8 & 3.7 & 8.1 & 0.1 & 8.2 & 0.770 & 732.5 \\
\hline
\end{tabular}




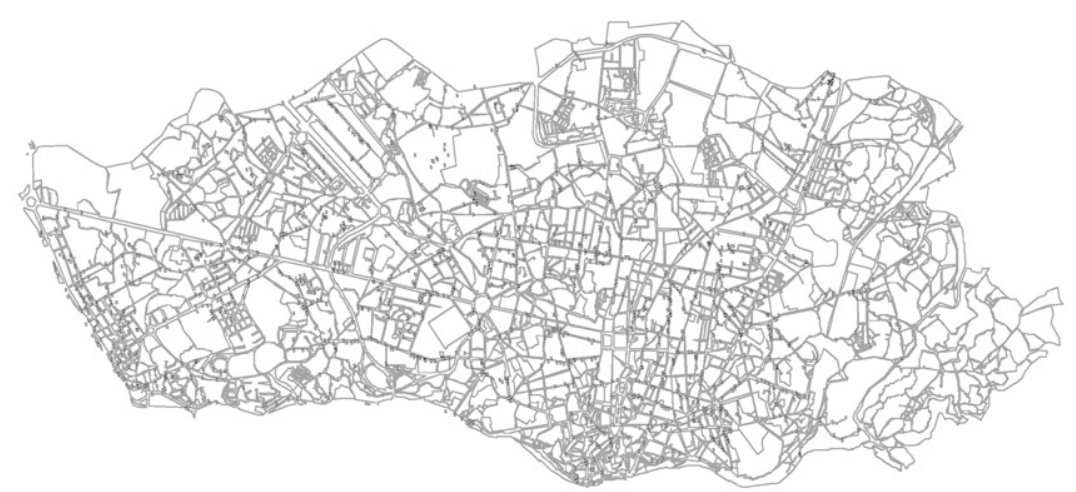
0 - 1403.0 Euros
1403 - 1433.5 Euros
1433.5 - 1457.5 Euros
1457.5 - 1486 Euros
$1486-1616$ Euros
Porto

Offices selling prices $/ \mathrm{m} 2$ in the 1 st. segment
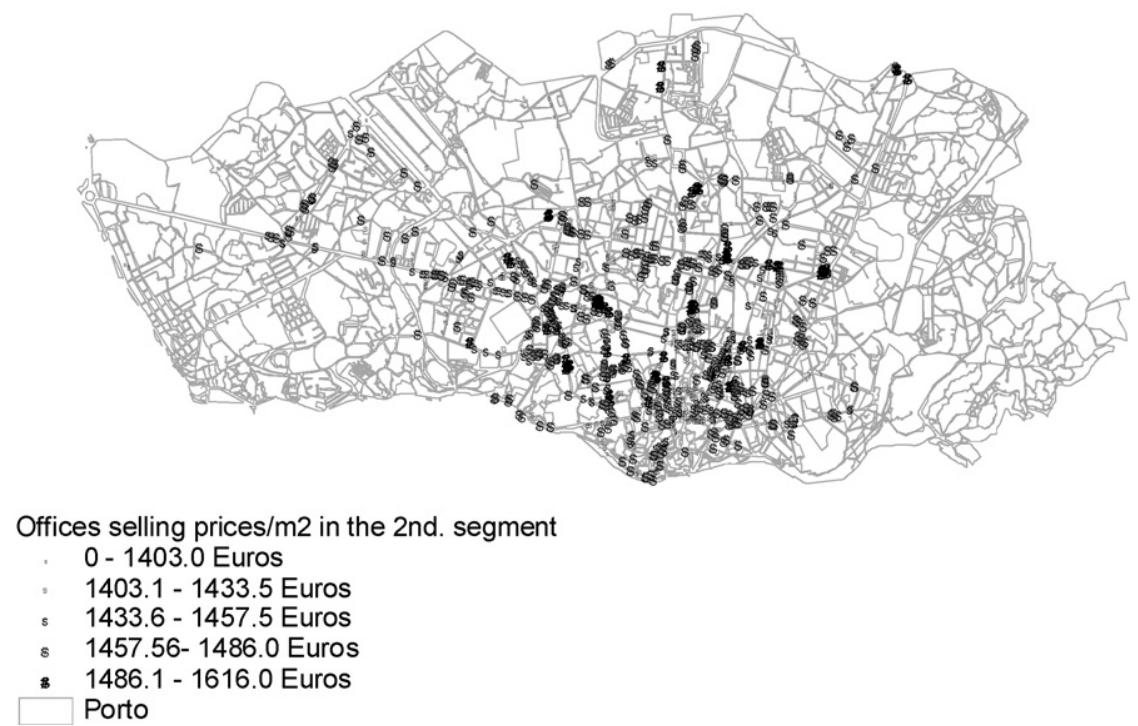

Fig. 3. Offices selling prices $/ \mathrm{m}^{2}$ in the first and in the second market price segments anticipated by the hedonic regression model.

worked out based on information collected from building firms (excerpts are displayed in Table 2).

Costs of plots per $\mathrm{m}^{2}$ of building area correspond to capitalised economic return on land use. They were determined considering respective list computed by Oporto City Council land division (Rebelo, 2003, 2004). These are based on selling prices of building plots designed to habitation and trade uses, performed by public auction - that nearly approach land socially-oriented prices. Offices were grouped according to geographic areas (sets of blocks) they belonged to. Values per $\mathrm{m}^{2}$ of land designed to offices were considered $25 \%$ lesser than corresponding selling prices $/ \mathrm{m}^{2}$ of land for commercial uses (according to the trends revealed in the recent past years, reported by the manager of this division) (Table 3).

Acquisition costs also include other parcels, expressed as a percentage of land acquisition cost $/ \mathrm{m}^{2}$ : (1) transfer tax (10\%); (2) stamp duty $(0.4 \%)$; (3) property registration costs $(0.5 \%)$; (4) notarial costs (0.5\%); and (5) lawyer honoraries (0.5\%).

Urbanisation costs - land infrastructure and participation in public equipments - were computed according to the municipal tax for the accomplishment of urbanistic infrastructures. ${ }^{2}$ The value of 31.5 euros used corresponds to about $53 \%$ of the urbanisation cost obtained from the average values of its different components in 1998 in the northern region (INE), because office undertakings are generally located in well infrastructured areas.

Construction costs include costs with building properly socalled, other equipment costs (namely heating systems, lifts and special foundations), and building honoraries. A value of 415 euros per office square meter was considered, according to Portuguese northern association of civil works and public works industrials, ${ }^{3}$ taking average common habitation selling price $/ \mathrm{m}^{2}$ in $2000 .^{4}$ This

\footnotetext{
2 In the computation of urbanisation costs was applied article $n^{\circ} 102$ of the Oporto City Council regulation of municipal works, according to the cost established in D.R. $\mathrm{n}^{\circ} 252-31$, and in the scope of the $\mathrm{n}^{\circ} 1$ of the 7 th article of the D. L. $\mathrm{n}^{\circ} 13 / 86$.

3 This value reports to document "Selling prices per $\mathrm{m}^{2}$ of construction" elaborated by A.I.C.C.O.P.N. (Associação dos Industriais de Construção Civil e Obras Públicas do Norte).

${ }^{4}$ According to views expressed by people currently working in the building sector, it can be considered that offices building costs are equivalent to common habi-
} 
Table 3

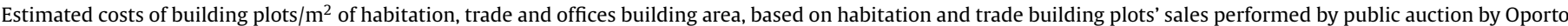
City Council (Source: Oporto City Council - adaptation)

\begin{tabular}{|c|c|c|c|}
\hline \multirow[t]{2}{*}{ Areas in Oporto city } & \multicolumn{3}{|c|}{ Building plot land cost per $\mathrm{m}^{2}$ of building area (euros) } \\
\hline & Habitation & Trade & Offices \\
\hline Corujeira/S. Roque da Lameira & 115.5 & 231.5 & 173.5 \\
\hline Ramalde/Monte dos Burgos & 109.5 & 219.0 & 164.0 \\
\hline Paranhos/Costa Cabral & 132.5 & 212.0 & 159.0 \\
\hline Aldoar/Antunes Guimarães/Vilarinho & 164.0 & 273.5 & 205.0 \\
\hline Marquês/Constituição & 150.5 & 301.5 & 226.0 \\
\hline Bonfim/Campo 24 de Agosto & 150.5 & 301.5 & 226.0 \\
\hline Antas & 188.0 & 281.5 & 211.5 \\
\hline Gonçalo Cristóvão/Baixa & 188.0 & 375.5 & 281.5 \\
\hline Boavista/Rotunda & 193.5 & 386.5 & 290.0 \\
\hline Foz/Gomes da Costa & 207.0 & 322.0 & 241.5 \\
\hline
\end{tabular}

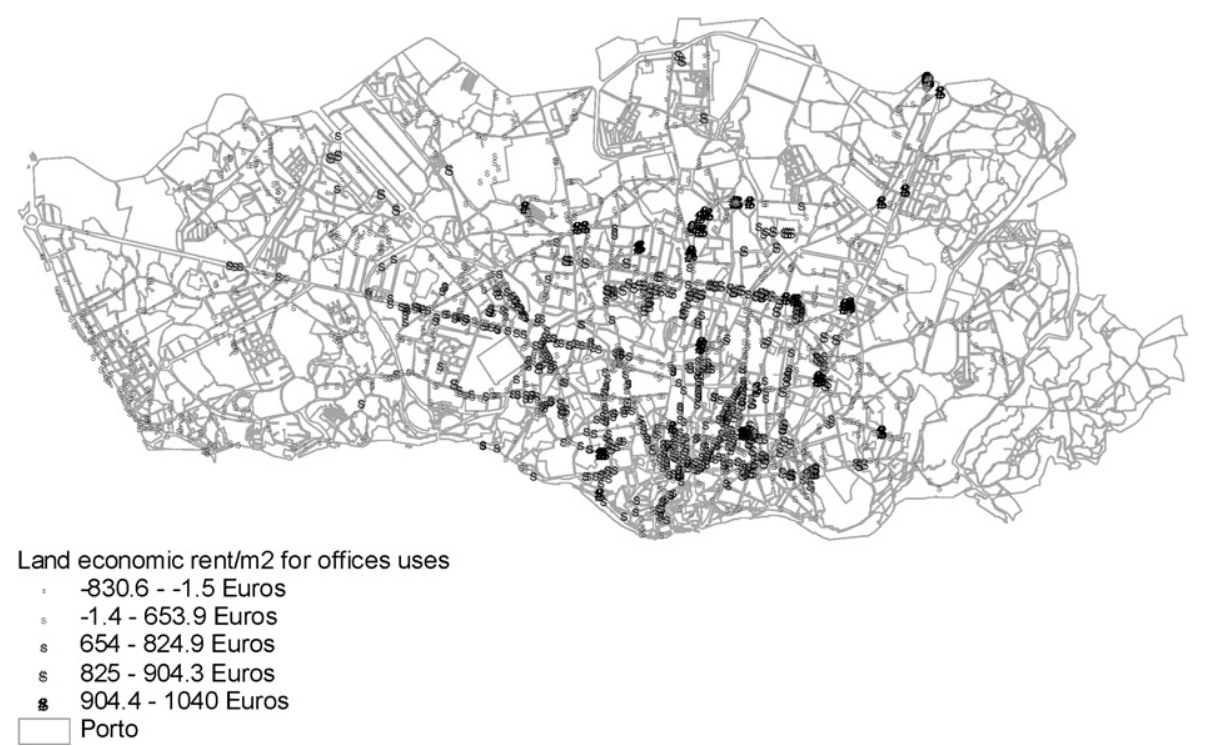

Fig. 4. Estimate of land economic rent for offices uses in the second offices market segment in Oporto city.

value also includes several contingent costs (that, usually, go up to $5 \%$ of the total costs), and the construction inflation.

Cost $/ \mathrm{m}^{2}$ of garages was assumed to amount to $87.5 € / \mathrm{m}^{2}$ weighed by 0.5 because garages' areas represent about half total offices' area. ${ }^{5}$

Management, administrative and marketing costs were supposed to represent $0.8 \%$ of the total office building costs $/ \mathrm{m}^{2}$. On those costs, falls on an accrued value tax of $21 \%$.

In what concerns the financial costs, a capital annual cost of $6.2 \%$, and an annual borrowed money of about $50 \%$ in land acquisition, and of $50 \%$ in the commercialization process were considered. Thus, costs of financing acquisition amount to $3.1 \%$ of total land cost $/ \mathrm{m}^{2}$, and costs of financing commercialization represent $3.1 \%$ of $0.5 \%$ of construction costs $/ \mathrm{m}^{2}$ (commercialization expenses are assumed to represent $0.5 \%$ of construction costs).

Finally, it was considered that the municipal property tax (which is the more important tax on real estate property), ascend to $0.77 € / \mathrm{m}^{2}$ for office, trade, industry and equipment uses, according to autarchic contribution data (Pardal et al., 1996)

tation building costs, assuming these costs already include financing to building processes.

5 In the computation of costs $/ \mathrm{m}^{2}$ of garages was applied article $\mathrm{n}^{\circ} 104$ of the Oporto City Council regulation of municipal works, that states in paragraph b), that "in the buildings where prevail the tertiary activities and great trade spaces, the parking area should be $50 \%$ of the usable area exclusively designed to those purposes".
Computation of economic rent and surplus values of land aimed at offices uses

Expected income per offices square meter was estimated for the second price segment - that truly represents institutional offices market's behaviour -, considering offices prices stabilization trend patent in last decade and in recent years (as referred previously, date is not actually an explanatory variable). It is given by the product between the number of storeys that can be built (considering an average height of $2.7 \mathrm{~m})^{6}$ and the anticipated selling price - according to the hedonic model. However, only $60 \%$ of this value was taken because it was previously admitted that, for each square meter, $60 \%$ is affected to offices and $40 \%$ to other uses, including public spaces. Economic rents $/ \mathrm{m}^{2}$ of land in current or designed to future offices uses were computed as the difference between selling price $/ \mathrm{m}^{2}$ and the totality of land, technical building, management, commercialization, administrative, marketing and financial costs and taxes, and a normal gross profit margin, all expressed by unity of area (Rebelo, 2003).

Fig. 4 cartographically displays economic rent of land designed to offices uses in Oporto city, according to the developed model.

From cartographic analysis it can be noticed that land economic rents reach higher values in Oporto downtown, city historical zone

\footnotetext{
${ }^{6}$ According to the general regulation of urban edifications R.G.E.U. (Regulamento Geral das Edificações Urbanas).
} 
Table 4

Estimate of economic rent and surplus values of land aimed at offices uses (second market segment) in Oporto city (excerpt of the database)

\begin{tabular}{|c|c|c|c|c|c|c|c|c|c|c|c|}
\hline Address & Area of Oporto city & $\begin{array}{l}\text { Land occupation } \\
\text { coefficient }\end{array}$ & $\begin{array}{l}\text { Number of } \\
\text { storeys }\end{array}$ & $\begin{array}{l}\text { Anticipated selling } \\
\text { prices } / \mathrm{m}^{2} \text { (euros) }\end{array}$ & $\begin{array}{l}60 \% \text { of the } \\
\text { income } / \mathrm{m}^{2}\end{array}$ & $\begin{array}{l}\text { Land, building, } \\
\text { management, } \\
\text { commercialization, } \\
\text { administrative, } \\
\text { marketing and } \\
\text { financial costs, } \\
\text { taxes } / \mathrm{m} 2 \text {, and } \\
\text { normal gross profit } \\
\text { margin } / \mathrm{m}^{2}\end{array}$ & $\begin{array}{l}\text { Land economic } \\
\text { rent } / \mathrm{m}^{2}(1)\end{array}$ & $\begin{array}{l}\text { Land rent } / \mathrm{m}^{2} \\
\text { (2) }\end{array}$ & $\begin{array}{l}\text { Land market } \\
\text { value } / \mathrm{m}^{2} \\
{[(3)=(1)+(2)]}\end{array}$ & $\begin{array}{l}\text { Land } \\
\text { patrimonial- } \\
\text { value } / \mathrm{m}^{2} \\
\text { (4) }\end{array}$ & $\begin{array}{l}\text { Surplus-values } \\
(4)-(3)\end{array}$ \\
\hline $\begin{array}{l}203 \text { RUA GUEDES } \\
\text { AZEVEDO R }\end{array}$ & Gonçalo Cristóvão/Baixa & 5 & 1.9 & 1554.3 & 1726.9 & 543.4 & 1183.6 & 281.5 & 1465.1 & 645.2 & 819.9 \\
\hline 227 RUA PINTO BESSA R & $\begin{array}{l}\text { Corujeira/S. Roque da } \\
\text { Lameira }\end{array}$ & 5 & 1.9 & 1260.8 & 1400.9 & 515.4 & 885.5 & 173.5 & 1059.0 & 745 & 314.0 \\
\hline 242 RUA S BRAS R & Gonçalo Cristóvão/Baixa & 5 & 1.9 & 1504.2 & 1671.3 & 543.4 & 1128.0 & 281.5 & 1409.5 & 649 & 760.5 \\
\hline $\begin{array}{l}2533 \text { FERNAO } \\
\text { MAGALHAES AVE }\end{array}$ & Paranhos/Costa Cabral & 5 & 1.9 & 935.3 & 1039.2 & 511.7 & 527.5 & 159.0 & 686.5 & 758.4 & -71.9 \\
\hline 35 RUA LIMA JUNIOR R & Paranhos/Costa Cabral & 5 & 1.9 & 1284.0 & 1426.7 & 511.7 & 915.0 & 159.0 & 1074.0 & 756.2 & 317.8 \\
\hline 411 RUA CASTELOS R & $\begin{array}{l}\text { Ramalde/Monte dos } \\
\text { Burgos }\end{array}$ & 5 & 1.9 & 1362.1 & 1513.5 & 513.0 & 1000.5 & 290.0 & 1290.5 & 753.8 & 536.7 \\
\hline $\begin{array}{l}433 \text { RUA NOSSA } \\
\text { SENHORA FATIMA R }\end{array}$ & Boavista/Rotunda & 5 & 1.9 & 1436.0 & 1595.6 & 545.6 & 1050.0 & 290.0 & 1340.0 & 637.4 & 702.6 \\
\hline 49 RUA FORMOSA R & Bonfim/Campo 24 Agosto & 5 & 1.9 & 1429.5 & 1588.3 & 528.9 & 1059.4 & 226.0 & 1285.4 & 659.5 & 625.9 \\
\hline $\begin{array}{l}55 \text { RUA DR RICARDO } \\
\text { JORGE R }\end{array}$ & Gonçalo Cristóvão/Baixa & 5 & 1.9 & 1377.0 & 1530.0 & 543.4 & 986.6 & 281.5 & 1268.1 & 659.2 & 608.9 \\
\hline 57 RUA FLORES R & Gonçalo Cristóvão/Baixa & 5 & 1.9 & 858.0 & 953.3 & 543.4 & 409.9 & 281.5 & 691.4 & 653.1 & 38.3 \\
\hline 393 RUA ALEGRIA R & Marquês/Constituição & 5 & 1.9 & 1472.4 & 1636.0 & 529.0 & 1106.9 & 226.0 & 1332.9 & 696.5 & 636.4 \\
\hline $\begin{array}{l}1395 \text { RUA } \\
\text { CONSTITUICAO R }\end{array}$ & Marquês/Constituição & 5 & 1.9 & 1304.9 & 1449.9 & 529.0 & 920.9 & 226.0 & 1146.9 & 694.3 & 452.6 \\
\hline $\begin{array}{l}455 \text { COMBATENTES } \\
\text { GRANDE GUERRA AVE }\end{array}$ & Antas & 5 & 1.9 & 1160.3 & 1289.2 & 525.3 & 764.0 & 211.5 & 975.5 & 705.8 & 269.7 \\
\hline 8 RUA BRAS CUBAS R & Antas & 5 & 1.9 & 1052.4 & 1169.3 & 525.3 & 644.0 & 211.5 & 855.5 & 705.1 & 150.4 \\
\hline
\end{tabular}

Antas

(

Unit: euros. 
and in all Boavista area, followed by locations along and around Constituição Street - precisely the ones where offices services are more densed.

The official valuation code (municipal tax on property, ruled by $\mathrm{DL} \mathrm{n}^{\circ} 287 / 2003$ ) establishes the parameters to compute real estate normal and reasonable prices $/ \mathrm{m}^{2}$, according to the application of a socially-oriented land policy. According to 38th, 40th, $41 \mathrm{st}$, 42nd and 45th articles, the tributary patrimonial-value of building land is given by the sum of the value of the building implantation surface with the value of land adjacent to construction. The former varies between $15 \%$ and $45 \%$ of edifications' value, provided that the chosen percentage considers location characteristics. Tributary patrimonial-value of urban edifications targeted to habitation, trade, industry and services uses is given by the product between (1) property base-value and (2) gross construction area plus area exceeding the implantation one; (3) affectation coefficient; (4) location coefficient; (5) comfort and quality coefficient; and (6) ancientness coefficient. The affectation coefficient (article 41st) varies according to urban property kind of use: trade, services, habitation, social habitation, warehouses and industrial activities, and parking. Location coefficient (article 42nd) depends on accessibilities, proximity to social equipments, proximity to public transportation services, and location in expensive real estate areas (however subjective this may be). Comfort and quality coefficient (article 43rd) of urban property designed to trade, industry and services, is positively weighted by location in trade centres or in building offices, existence of central air conditioned, building quality and existence of lifts or rolling stairs, and negatively weighted by inexistence of sanitary installations, water and electricity nets, sewerage system, paved streets, lifts in buildings with more than three floors and low maintenance conditions. The ancientness coefficient (article 44th) is dependent on building's number of years.

This article proposes the computation of surplus values as the difference between land market value and correspondent tributary patrimonial-value $/ \mathrm{m}^{2}$ of each office location and characteristics that results from the application of property official code. Once only urbanistic explanatory variables were considered in the hedonic model, this assures surplus values only depend on territorial-base value, thus their tributation is neutral in face of landowner's interests. Land market values are given by the sum of land rent (that corresponds to the economic return on land use, previously computed), and land economic rent. Patrimonial-values, by their turn, are computed to all offices using DL $n^{\circ} 287 / 2003$. Of course this surplus value includes an additional profit, but as distinction between these two components is difficult, urban planning shall negotiate the distribution of surplus values among itself, landowners and promoters (Pardal, 2006a).

Table 4 presents some excerpts of the database used in the computation of surplus values $/ \mathrm{m}^{2}$ for each geo-referenced secondsegment office location in Oporto city.

It can be noticed, through correspondent cartographic display, that higher surplus values concentrate along Constituição Street (and street layout confluent with it), Antas area, and Oporto downtown, followed by Rotunda of Boavista's surrounding area, and along Boavista Avenue (Fig. 5): these are the areas that deserve particular attention from urban planning settings.

This integrated model - together with its permanent updated articulation with presented databases and cartographic displays - took urbanistic parameters settled in Oporto 1993rd Municipal Master Plan, and allows computation of surplus values according to a supposed reasonable and fair regulating land policy settled by law. It is intended to provide an economic-financial and cartographic support to urban policy decisions, in matters such as land use management (including taxation choices), and location of economic activities, particularly in offices' fields. The methodology that informs it can include new and updated information, allowing on-going monitoring and control of factors that exert impact on offices real estate and land values. The simulation and cartographic interface allow analysis, computation and display of land economic rent and surplus values changes that result from variations in input planning-related variables, under a spatial perspective. It can be generalized to whichever offices potential location is (within areas defined for services uses in the city Master Plan), since physical and legal possibilities exist for building offices. It is also replicable elsewhere and adjustable to other urban realities due to its flexibility and feedback structure.

These kinds of models to evaluate, compute and quantify surplus values should inform territorial plans in order to appraise impacts exerted by administrative decisions concerning land use or intensity of use changes, and public investments. They are proposed in this article as a basis for the application of a more territory-related

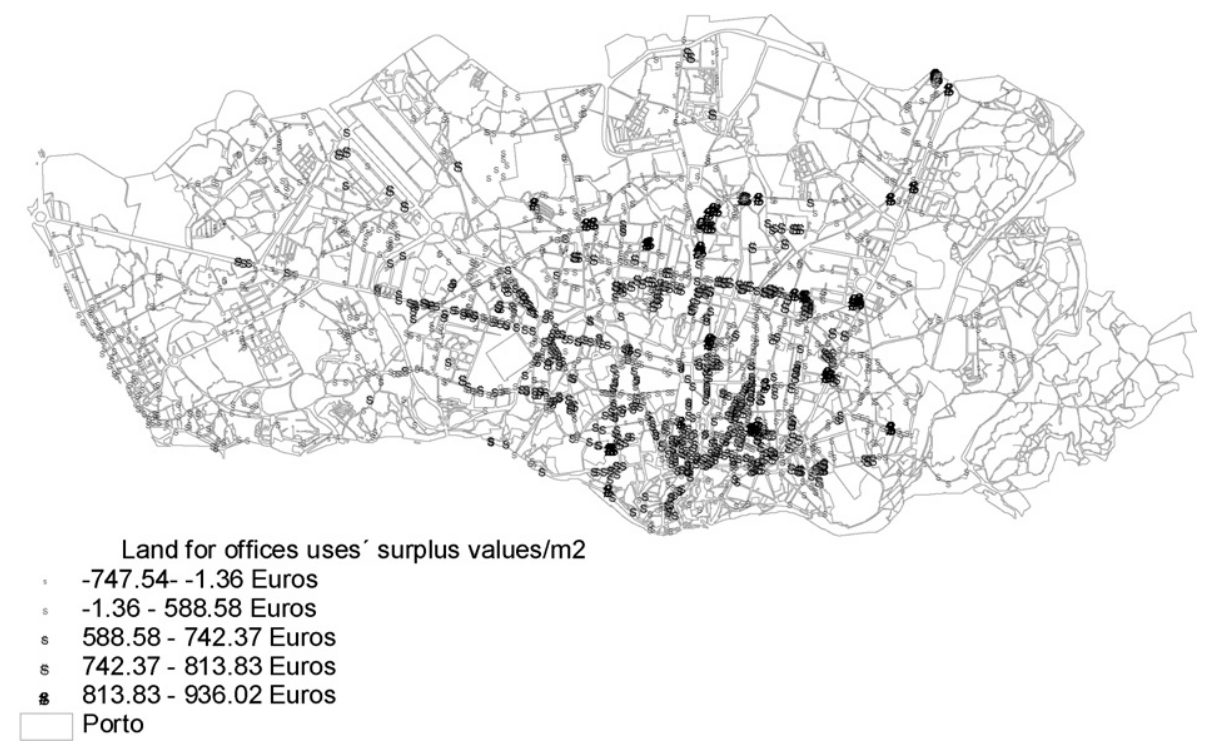

Fig. 5. Expected surplus values in Oporto city, according to proposed methodology. 
surplus values taxes' policy - founded on local intrinsic economic, social and functional characteristics.

\section{Discussion and conclusions}

One of the greatest challenges urban planning currently faces consists in the evaluation of its accrued impact on overall territorial political-economic fields (Barker and Sa-Aadu, 2004). This article is expected to make a contribution to the debate concerning impacts exerted by urban planning over land and real estate values - namely in what concerns land economic rents and surplus values engendered by administrative processes. Planning strategic regulation role is enhanced in theoretical and in practical terms, as a warrant to land availability for different uses at acceptable prices (Pardal, 2006b).

Land rent theory is reassessed, informing a reflection on urban property phenomena. Reciprocal cause-and-effect relations between land and real estate are analysed, in order to justify political-economic planning and taxation intervention processes (Anderson, 2005; Arnott and Petrova, 2006; Jäger, 2003; Lee, 2003; Lim, 1999; Smolka and Amborski, 2003).

A neo-classical Ricardian perspective is adopted in what concerns the influence exerted by real estate supply on land rents (Aydalot, 1985; George, 1879; Ricardo, 1817; Smith, 1843; Spiegel, 2001; Topalov, 1973), although complemented with reflections about the impact land rents themselves exert on real estate values (Dunn, 1954; Halbwachs, 1909; Harvey, 1985; Needham, 1981).

Territorial plans, zoning ordinances, land use coefficients and public investments strongly condition real estate assets and land prices (Clark, 1995; Hui and Ho, 2003; White and Paster, 2003). Besides, location choices of private economic activities exert important constraints upon urban land rent (LaFountain, 2005), and on offices prices (Henneberry et al., 2005). Although computation of the impacts exerted by different variables on offices prices is straightforward (Dunse and Jones, 1998, 2002; Nappi-Choulet et al., 2007; Nitsch, 2006), the same does not necessarily hold true for land values, because political, economic and psychological factors, together with property rights and planned uses and regulations mingle altogether and strongly impact on their values. But these factors are increasingly disconnected from land revenue as a production factor, and are more and more dependent on territorial plans (Pardal, 2006a).

Some insights are added to the relations between theory and practise in spatial land use planning - particularly in offices markets - (Dunse and Jones, 2002; Nappi-Choulet et al., 2007; Nitsch, 2006), in both qualitative and quantitative fields, in order to tackle planning effects on territory, informing a better local-founded urban policy in face of property rights, and of different involved interests, warranting land social function (Needham, 2000; Needham and Verhage, 1998; Pardal, 2006a). A large path for urban planning and fiscal policy intervention is open up through development of urban management tools, assessed in this article. Besides the identification of qualitative factors that condition and guide urban planning performance, quantitative tools are assuming increasing importance, in face of the development of hedonic models that embody large mass appraisal functionalities (Bengochea-Morancho, 2003; Bourassa et al., 1999; McCluskey et al., 1997; McGreal et al., 1998; Royal Institution of Chartered Surveyors, 1994, 1996). Here is proposed a systematic hedonic methodology to operationalise and compute factors underlying real estate use-oriented offices and land aimed at offices uses' pricing structure. However stated differently, this point converges with other studies developed in the field, that consider the final price of built spaces are given by the sum of their normal value with surplus values and opportunity profits where normal value, by its turn, is given by the sum of land cost with costs of projects and administrative, urbanisation and building charges, plus promotion profits (Pardal, 2006a).

Portuguese planning tools must urgently follow a strategic view, in order to control speculation, balance public and private interests, rule relations between the public scope and land property rights, and prompt a better sustained development and life quality for all citizens (Pardal, 2006a). Thus urban planning shall pursue the goals stated by a clear and balanced land policy, able to make land available in due course for different kinds of uses, at reasonable prices, and assuring real estate final prices place within a range of socially acceptable parameters (Anderson, 2005; Pardal, 2006b). As development is usually carried on by private initiative, urban planning has a core responsibility in arranging tasks and competencies of the public and private sectors, what implies a clear legislative definition of property rights and duties (Pardal, 2006a,b). City councils must strategically tender their territorial plans, clearly stating real estate products they intend to encourage and forward, and land resources needed for their implementation, considering land plots' dimensions, characteristics and locations, establishing patterned-reference prices that rule the market. Then they must allot development land between public, private, and public-private partnerships (Pardal, 2006a). In Portugal land law is currently under revision, but in Spain the homologous law was recently approved, including measures in order to assure higher transparency processes and population's participation in plans, thus avoiding speculation and corruption.

Urban planning should develop proceedings to settle parameters and compute surplus and loss values in order to allow a clear and trusted territorial administration, in coordination with a land use law that defines appropriate regulating prices considering land social function. This informs monitoring and evaluation proceedings, as far as economic-financial impacts it exerts on particular territories are concerned. It must exert control on land prices through benchmarking, in order to keep each site and each use within the range of land rent capitalization supported by respective uses, as anticipated in territorial plans (Pardal, 2006a,b). In this sense, this article proposes a methodological assessment and computation of influences exerted by planning variables (namely zoning ordinances, land use coefficients and public investments) on real estate and land price formation. It additionally provides an integrated model for computation of economic rent and surplus values of land designed to offices uses. This model is set up by a set of tools aimed at supporting municipal decisions. Still more, it enables new and updated information inclusion, on-going monitoring of variables that exert impact on price levels, and simulation of alternative scenarios for urban planning intervention, as well as their prompt cartographic display. Whenever some planning intervention affects offices real estate and territorial values, accrued values should be computed through the proposed model - in relation to the reference model developed for 1999th offices market.

Plans should clearly be endowed with studies to assess real estate and land price formation, with price-maps, and with surplus appraisal models like this one in order to analyse and quantify economic-financial impacts of planning tools on territory. Indeed these sets of tools should be formatted in order to disclose local specific realities, and express the increasing importance of new local territorialities (Pardal, 2003, 2006a).

Urban planning will only manage to effectively control land prices if it is able to grant land supply higher than demand. This can be accomplished if it intervenes straightly in the market - through formation of a municipal land exchange - or indirectly, through incentives to make available alternative land plots, namely through fiscal means (Pardal, 2003).

Landowners try to enhance their plots' location unique characteristics that mean land monopolistic components, what aggravates 
development costs (Evans, 1999; Harvey, 1978; Marx, 1867). If land supply is quite inelastic, then almost all engendered revenue will convert into economic rent. Urban planning interventions warrant better clearliness and fluidity to market performance, namely urging competition and assuming itself as a market land supplier. This increases land elasticity supply, thus reducing economic rent and surplus values retained by private parts. Through these tools urban planning keeps surplus values on their own, therefore it is desirable land passes through public property - or application of similar mechanisms allows its auction-price appraisal. These proceedings do not engender conflict situations, and support planning tasks in order to discipline urban development and to balance land markets. However, urban planning can still monitor, control and reassess accrued values through taxation and ruling tools on an a posteriori basis (Correia, 1993; Gwin et al., 2005; Pardal et al., 1996; Smolka and Amborski, 2003).

In order to counteract abnormal price rises in certain geographical areas, plans should be able to generate alternative centralities through land supply at attractive prices, and able to normalise and balance price levels. This occurred with 1993rd Oporto Master Plan, where a modern central business district was settled in Boavista area, where existed expectant land plots with provisional uses. This measure allowed the development of a new cleared-up centrality alternative to the traditional one that was near buildingsaturation and where price levels reached height tops due to land monopoly-supply constraints.

As surplus values are engendered by administrative decisions of municipalities - that are the entities that detain power to decide on land use changes or land use intensity changes, and that have the responsibility to rule land and real estate markets -, they should involve a trading process among the municipality itself, landowners and urban development and construction promoters. All participants in the development productive chain should be encouraged to bring in respective added value, thus reaching acceptable profit margins within market and urbanistic rules, and respecting land use policy principles (Clark, 1995; Correia, 1993; Pardal, 2006a,b). Otherwise development processes risk to be blocked either by supply or by demand forces.

\section{References}

Anderson, J.E., 2005. Taxes and fees as forms of land use regulation. Journal of Rea Estate Finance and Economics 34, 413-427.

Arnott, R., Petrova, P., 2006. The property tax as a tax on value: deadweight loss. International Tax and Public Finance 13, 241-266.

Aydalot, P., 1985. Économie régionale et urbaine (“in French”). Economica, Paris, 487

Barker, D., Sa-Aadu, J., 2004. Is real estate becoming important again? A neo-classica Ricardian model of land rent. Real Estate Economics 32, 33-53.

Bengochea-Morancho, A., 2003. A hedonic valuation of urban green areas. Landscape and Urban Planning. 66, 35-41.

Bourassa, S.C., Hamelink, F., Hoesli, M., MacGregor, B.D., 1999. Defining housing submarkets. Journal of Housing Economics 8, 160-183.

Chacholíades, M., 1986. Microeconomics. MacMillan Publishing Company, New York, 629 pp.

Clark, E., 1995. The rent gap re-examined. Urban Studies 32, 1489-1504.

Correia, P., 1993. Políticas de solos no planeamento municipal ("in Portuguese") Edição da Fundação Calouste Gulbenkian, Lisboa, 403 pp.

Correia, P.V.D., Silva, F.N., 1987. The peripheral city - urban development in Lisbon. The Planner (March), 25-27.

Dubin, R., 1998. Predicting house prices using multiple listings data. Journal of Rea Estate Finance and Economics. 17, 35-59.

Dunn, E.S., 1954. The Location of Agricultural Production. University of Florida Press, Gainesville, FL, 237 pp.

Dunse, N., Jones, C., 1998. A hedonic price model of office rents. Journal of Property Valuation and Investment 16, 297-312.

Dunse, N., Jones, C., 2002. The existence of offices submarkets in cities. Journal of Property Research 19, 159-182.

Evans, A., 1999. On minimum rents. Part 1. Marx and absolute rent. Urban Studies $36,2111-2120$

George, H., 1960. Progress and Poverty (1st ed. 1879). Schalkenbach Foundation, New York, $406 \mathrm{pp}$
Granelle, JJ., 1970. Éspace urbain et prix du sol. Recherches Économiques et Financières 14 ("in French". Editons Sirey, Paris, 296 pp.

Gwin, C.R., Ong, S.E., Spieler, A.C., 2005. Auctions and land values: an experimental analysis. Urban Studies 42, 2245-2259.

Halbwachs, M., 1909. Les expropriations et le prix des terrains à Paris (1860-1900) ("in French"). Cornely, Paris, 416 pp.

Harter-Dreiman, M., 2004. Drawing inferences about housing supply elasticity from house price responses to income shocks. Journal of Urban Economics 55, 316-337.

Harvey, D., 1978. The urban process under capitalism: a framework for analysis. International Journal of Urban and Regional Research 2, 101-131.

Harvey, D., 1985. The Urbanization of Capital. Studies in the History and Theory of Capitalist Urbanization. Johns Hopkins University Press, Baltimore, 259 pp.

Henneberry, J.M., McGough, T., Mouzakis, F., 2005. The impact of planning on local business rents. Urban Studies 42, 471-502.

Hong, Y., 1998. Transaction costs of allocating increased land value under public leasehold systems: Hong Kong. Urban Studies 35, 1577-1595.

Hui, S.C.M., Ho, V.S.M., 2003. Does the planning system affect housing prices? Theory and with evidence from Hong-Kong. Habitat International 27, 339-359.

Jäger, J., 2003. Urban land rent theory: a regulationist perspective. International Journal of Urban and Regional Research 27, 233-247.

LaFountain, C., 2005. Where do firms locate? Testing competing models of agglomeration. Journal of Urban Economics 58, 338-366.

LeFeber, 1958. Allocation in Space: Production, Transport, and Industrial Location. North Holland Publishers, Amsterdam, 254 pp.

Lee, K., 2003. Should land and capital be taxed at a uniform rate? Canadian Journal of Economics 36, 350-372.

Lichfield, N., Darin-Drabkin, H., 1980. Land Policy in Planning. HarperCollins Publishers Ltd., London, $344 \mathrm{pp}$

Lim, D.-H., 1999. The Relative efficiency of taxes in a two-period model of urban growth. Journal of Urban Economics 45, 403-420.

Lipsey, R.G., Chrystal, K.A., 1983. An Introduction to Positive Economics (1st. Ed. 1972). Oxford University Press, Oxford, $943 \mathrm{pp}$

Marx, K. 1960 Le capital, 1re. Éd. 1867-1885; Rééd. Ed. Sociales (Liv. III, t. III, 6e sect).

McCluskey, W., Deddis, W., Mannis, A., McBurney, D., Borst, R., 1997. Interactive application of computer assisted mass appraisal and geographic information systems. Journal of Property Valuation and Investment 15, 448-465.

McGreal, S., Adair, A., McBurney, D., Patterson, D., 1998. Neural networks: the prediction of residential values. Journal of Property Valuation and Investment 16 $57-70$.

Morphet, C., 1997. A statistical method for the identification of spatial clusters. Environment and Planning A 29, 1039-1055.

Nappi-Choulet, I., Maleyre, I., Maury, T.P., 2007. A hedonic model of office prices in Paris and its immediate suburbs. Journal of Property Research 24, 241-263.

Needham, B., 1981. A neo-classical supply-based approach to land prices. Urban Studies 18, 91-104.

Needham, B., 2000. Spatial planning as a design discipline: a paradigm for Western Europe? Environment and Planning B-Planning and Design 27, 437-453.

Needham, B., Verhage, R., 1998. The effects of land policy: quantity as well as quality is important. Urban Studies 35, 25-44.

Nitsch, H., 2006. Pricing location: a case study of the Munich office market. Journal of Property Research 23, 93-107.

Pardal, S., 2003. Mercado Imobiliário, fiscalidade e planeamento do território ("in Portuguese"), Instituto Superior de Economia e Gestão, Centro de Investigação sobre Economia Portuguesa, Sidónio Pardal, 17th June.

Pardal, S., 2004. A fiscalidade e o ordenamento do território ("in Portuguese"). Faculdade de Direito de Lisboa, 15th to 19th November.

Pardal, S., 2006a. A apropriação do território. Crítica aos diplomas da RAN e da REN ("in Portuguese"). Ingenium Edições, Lda., Ordem dos Engenheiros, $167 \mathrm{pp}$.

Pardal, S., 2006b. Os planos territoriais e o mercado fundiário ("in Portuguese") XVI Congresso da Ordem dos Engenheiros, 2nd to 4th October, Ponta Delgada, Açores.

Pardal, S., Vaz, A Aubyn, A., Natário, I., Leitão, J., Costa, J., Lilaia, J.; Reynolds, M. Lobo, M., Tomé, M., Fallen, P., Costa, P., Fernandes, R., Galvão, S., Oliveira, V., 1996 Contribuição Autárquica: Impostos de Sisa, Sucessões e Doações e Mais Valias ("in Portuguese"). Ministério das Finanças - Secretaria de Estado dos Assuntos Fiscais; Universidade Técnica de Lisboa - G.A.P.T.E.C., Lisboa, 95 pp.

Peto, R., 1997. Market information management for better valuations. Part II. Data availability and application. Journal of Property Valuation and Investment 15, 411-422.

Rebelo, E.M. 2003. Mercado Imobiliário e Transformações Urbanas (Real Estate Market and Urban Changes - in Portuguese). PhD Thesis. Faculdade de Engenharia da Universidade do Porto, Porto, 827 pp.

Rebelo, E.M., 2004. Modelos de Avaliação Imobiliária e Fundiária aplicados ao Mercado de Escritórios ("in Portuguese"). Revista Portuguesa de Estudos Regionais 7, 41-62.

Ricardo, D., 1962. On the Principles of Political Economy and Taxation (1st. Ed. 1817). Cambridge University Press, Cambridge, 305 pp.

Rosen, S., 1974. Hedonic prices and implicit markets: product differentiation in pure competition. Journal of Political Economy 82, 34-55.

Royal Institution of Chartered Surveyors, 1994. Mallison Report: Commercial Property Valuations. Royal Institution of Chartered Surveyors, London.

Royal Institution of Chartered Surveyors, 1996. RICS Appraisal and Valuation Manual. Royal Institution of Chartered Surveyors, London. 
G Model

Smith, A., 1843. Recherches sur la nature des causes de la richesse des nations ("in French"). Guillaumin, Paris, 1re. Ed. 1776, 724 pp.

Smolka, M., Amborski, D., 2003. Recuperación de plusvalías para el desarrollo urbano: una comparación inter-americana (“in Spanish"). EURE - Revista LatinoAmericana de Estudios Urbano Regionales 29, 55-77.

Spiegel, M., 2001. Housing return and construction cycles. Real Estate Economics 29, 521-551.
Thoman, R., Conkling, E., Yeates, M., 1968. The Geography of Economic Activity. McGraw-Hill, New York, 602 pp.

Topalov, C. 1973. Capital et propriété foncière (“in French”). Paris: Centre de Sociologie Urbaine, Paris.

White, S.M., Paster, E.L., 2003. Creating effective land use regulations through concurrency. Natural Resources Journal 43, 753-779.

Please cite this article in press as: Rebelo, E.M., Land economic rent computation for urban planning and fiscal purposes. Land Use Policy (2008), doi:10.1016/j.landusepol.2008.07.008 